\section{Nomenclature}

$C=$ set of candidates

$D_{i}=$ node corresponding to pressure drop in the tank-pipeline system

$d=$ tolerance limit

$F_{i}=$ node corresponding to flow rate in the tank-pipeline system

$M=$ set of observed nodes in the weighted signed directed graph

$N=$ set of nodes in the weighted signed directed graph

$P_{i}=$ node corresponding to pressure in the tank-pipeline system

\section{Literature cited}

1) Gujima, F., B. Shibata, Y. Tsuge, H. Matsuyama and E. O'Shima: Kagaku Kogaku Ronbunshu, 16, 899 (1990)

2) Iri, M., K. Aoki, E. O'Shima and H. Matsuyama: J. Oper. Res. Soc. Japan, 23, 295 (1980)

3) Shibata, B. and H. Matsuyama: Kagaku Kogaku Ronbunshu, 15, 385 (1989)

4) Shibata, B., Y. Tsuge and H. Matsuyama: ibid., 16, 882 (1990)

5) Tateno, S., B. Shibata, Y. Tsuge and H. Matsuyama : ibid., 19, 30 (1993)

6) Tsuge, Y., J. Shiozaki, H. Matsuyama, E. O'Shima, Y. Iguchi, M. Fuchigami and M. Matsushita: ibid., 10, 531 (1984)

\title{
Evaluation of Accuracy of a Fault Diagnosis System Utilizing Transfer Delay of the Failure
}

\author{
Kazuhiro Takeda, BohYoh Shibata, Yoshifumi Tsuge \\ and Hisayoshi Matsuyama
}

Dept. of Chem. Eng., Kyushu Univ., Fukuoka 812

Key Words : Systems Engineering, Fault Diagnosis, Graph Theory, Weighted Signed Directed Graph, Evaluation of Accuracy

A method of evaluating the accuracy of fault diagnosis based on a weighted signed directed graph with delay is described. A tank-pipeline system is taken as an example to show the usefulness of this method and the influence of the value of allowance on the accuracy of fault diagnosis.

\section{流体振動による気泡塔内の液の軸方向混合特性の変化 ${ }^{\dagger}$ \\ 高橋憲司 ${ }^{*}$ 鍛治宗義・森茂・谷本 明 \\ 金沢大学工学部 物質化学工学科 ${ }^{\dagger \dagger}$}

Harbaum とHoughton ${ }^{3)}$ は気泡塔による炭酸ガスの吸 収実験を行い，振動を付加した場合に液相容量係数が 40 \%も増加したと報告している. 気泡塔内の液の混合特性

† 1992年 4 月13日受理 ; 化学工学会第 23 回秋季大会 (金沢, 1990年10月）にて一部発表

†† 920 金沢市小立野 2-40-20

* 北海道大学工学部 原子工学科
は気泡の運動に大きく影響されることを考えると， Harbaum とHoughtonの流体に振動を与えた実験では， 容量係数の増大のみならず液混合特性も大きく変化して いると予想されるがこの点に関する研究を見いだすとと はできない。本研究では, 液の軸方向混合拡散に及ぼす 振動の効果を, 標準気泡塔と多段気泡塔について検討し た. 


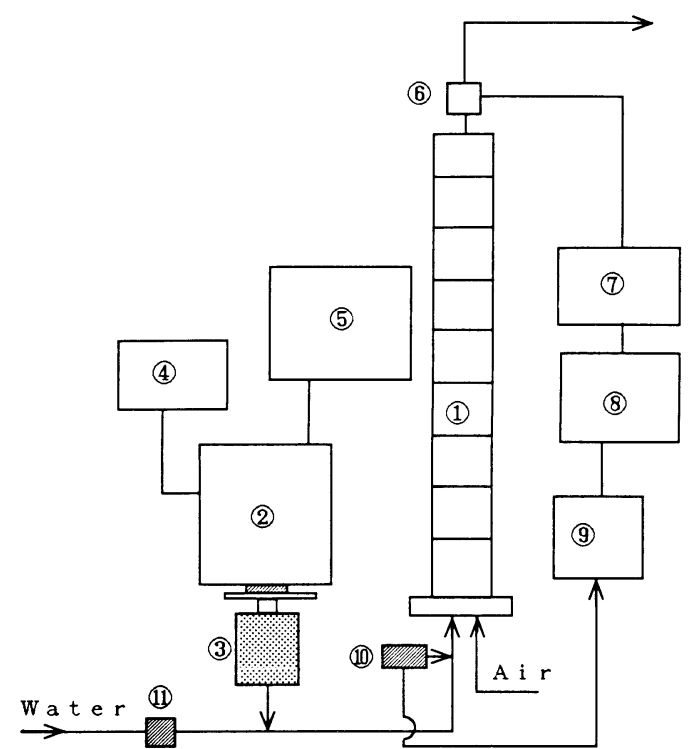

1. column; 2. electromagnetic vibrator; 3. piston and cylinder; 4 . acceleration pickup; 5 . power amplifier; 6 . electric conductivity cell; 7 . strain amplifier; 8. digital storage recorder; 9 . trigger; 10. syringe; 11 . check valve

Fig. 1 Schematic diagram of the experimental apparatus

\section{1. 実験装置および方法}

実験装置の概略図をFig. 1 亿示す，気泡塔として塔高 $100 \mathrm{~cm}$ ，内径 $5.0 \mathrm{~cm}$ の円管を用いた。塔入口部直前には トレーサ注入口を設けてあり, 塔出口部にはトレーサ濃 度を電気伝導度法により検出するための白金電極を設け てある.トレーサとしては $\mathrm{NaCl}$ 水溶液を用い, シリン ジによりパルス的に円管入口部直前より約 $1 \mathrm{~cm}^{3}$ 注入し た. 電磁バイブレーターでピストン部を正弦的に上下運 動させることにより流体に正弦的振動を与えた。流体と しては水道水を用いた。 コンプレッサーからの空気をフ ィルターで洗浄した後に気泡塔底部より塔内に供給した。 液は塔内で空気と並流接触し, トレーサー濃度测定用の 白金電極を経て排出される.

多段化のための仕切板としては，円板に同心円の穴を 開けたリング状の屯のを使用し，その開口比 $\phi$ が 0.25 , $0.5,0.75$ の 3 種類を用意した. 仕切板は塔内径と等しい 間隔で設置した。ガススパージャーにはガラスで作成し た単孔ノズルを使用した。ノズルの内径は $1.5 \mathrm{~mm}$ であ る. 電気伝導度セルには $10 \times 10 \mathrm{~mm}^{2}$ の白金板を $5 \mathrm{~mm}$ の 間隔で 2 枚向かい合わせにしたものを用いた。

排出液のトレーサー濃度の変化は電気伝導度セルによ り検出し 12 bit のデジタル記録計により測定した. 塔出
Table 1 Experimental conditions

Inside diameter of column

Column length

Hole diameter of partition plate

d $[\mathrm{mm}] 50$

$l \quad[\mathrm{~mm}] 1000$

$d_{B}[\mathrm{~mm}] 12.5$, $25.0,37.5$

Compartment hight

Liquid flow rate

$H \quad[\mathrm{~mm}] 50$

Gas flow rate

Amplitude of fluid vibration

Frequency of vibration

$u_{L}[\mathrm{~cm} / \mathrm{s}] \quad 0.5$

$u_{G}[\mathrm{~cm} / \mathrm{s}] \quad 0.5 \sim 15.0$

a $\quad[\mathrm{mm}] \quad 0 \sim 3.0$

f $[\mathrm{Hz}] 10.0$

口とセルとの間の時間遅れは計算により補正した。多段 気泡塔のモデルとしていくつかの報告 ${ }^{6,7)}$ があるが, 本研 究では応答曲線の解析は拡散モデルを仮定し, 液の見か けの軸方向拡散係数 $\mathscr{D}_{L}$ の評価を行った。滞留時間分布 関数 $E(\theta)$ の最大值を与える $\theta_{\max }$ の值と, あらかじめ求 めておいた $\theta_{\max }$ とボーデンシュタイン数 $P e B$ との関係 より帯留時間分布を解析し，PeBを算出した ${ }^{4)} . P e B$ は 通常のペクレ数 $u_{L} d / \mathscr{D}_{L}$ に変換した. 実験条件をTable 1 に示した。

\section{2. 実験結果と考察}

初めに，単相流における液混合特性に及ぼす振動の影 響について検討する．仕切板を有する円管内定常流に振 動を付加した場合の滞留時間分布の変化を Fig. 2 に示し た. 流体振動の振幅 $a$ が $2.0 \mathrm{~mm}$ までは振幅の増大につ れ $E(\theta)$ の最大值が減少し，そのときの $\theta$ の值が 1.0 亿近 ゔく傾向がみられる. 一方, $a=3.0 \mathrm{~mm}$ では, $E(\theta)$ の最 大值は増大して，プラグフロー的分布形状になり，混合 特性が振動付加により大きく変化することがわかる.

Fig. 3 にe 数の変化を示した. 仕切板の開孔比 $\phi$ が 0.5 の場合に振動の影響が最も大きく現れ， $\phi$ が 0.25 の場合 では液混合特性に及ぼす振動の影響は他の場合に比較し て小さい.一方, 図には示していないが, 仕切板を設置 しない場合は，Fig. 3 に見られるほよ゙大きな変化はない あのの, 振動を付加 $(a=1.0 \sim 5.0 \mathrm{~mm}, f=10 \mathrm{~Hz})$ した乙 とにより $P e$ 数は最大で 2 倍まで増大した。乙れは, 振 動付加により速度分布が平坦な分布に変化したためと考 えられる.Fig. 3 には Mackley ら ${ }^{2)}$ による実験結果を著 者らが整理して示してある. 彼らは断面が二角形状の仕. 切板を塔内 (内径 $0.023 \mathrm{~m}$ ) に設置し, 軸方向混合に及ぼ す振動の影響 $(a=0 \sim 5 \mathrm{~mm}, f=0 \sim 3.7 \mathrm{~Hz}$ ) を研究して いる，彼らの得た結果では，軸方向の混合を抑える最適 な振幅比が存在し，あまり大きな振幅で流体を擋乱する と見かけ上の軸方向混合が助長されることを示している。 また，Fig. 3 に示した実線は，仕切板として多孔板を用 いたパルスカラム (塔内径 0.032, $0.054 \mathrm{~m}, a=0 \sim 15 \mathrm{~mm}$, $f=0.4 \sim 3.0 \mathrm{~Hz})$ について Miyauchi とOya ${ }^{5)}$ が提出した 


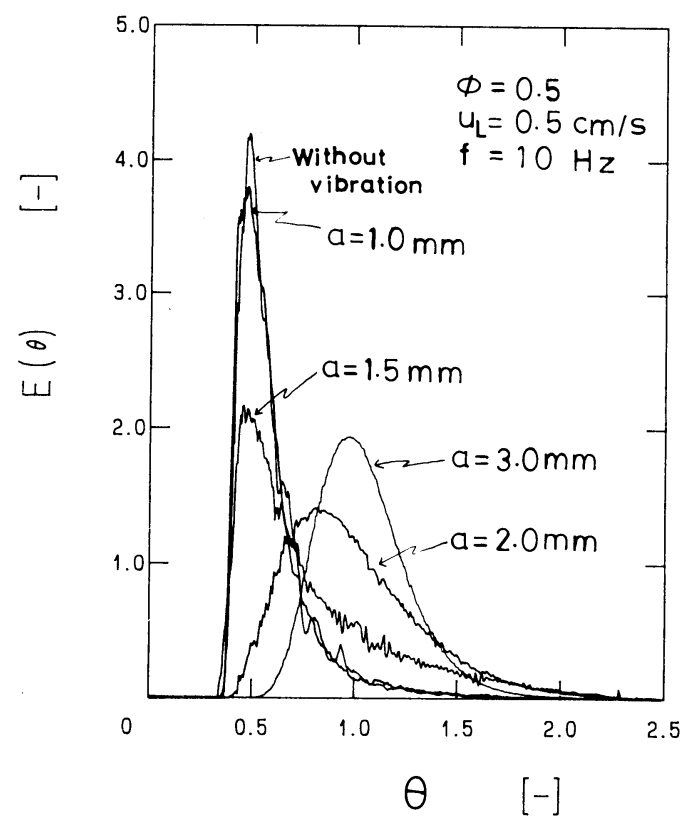

Fig. 2 Change of residence time distribution due to fluid vibration for a single phase flow in a multi-stage column

実験式より，著者らが計算した値である，振幅比に対す る $P e$ 数の変化の仕方は, Mackley らの $a / d>0.04$ にお ける傾向とにているが, Pe 数の值自身は本結果拉よび Mackleyらの結果と大きく異なる．乙れは，用いた仕切 板の形状が異なることに起因すると考えられる.

次に, 二相流に㧍ける液混合特性に及ぼす振動の影響 について検討する. 結果をFig. 4 亿示した. 矢印で示し た值は，振動を付加しない場合の $P e$ 数の值である．仕： 切板を設けない標準気泡塔では, $u_{G} \leqq 1.0 \mathrm{~cm} / \mathrm{s}$ の場合, 振動の振幅の増大につれ $P e$ 数は増大し, 本実験範囲で は約 3 倍まで増加がみられた。一方， $u_{G} \geqq 3.0 \mathrm{~cm} / \mathrm{s}$ では 振動の影響はほとんど観測されず， $u_{G}=3.0 \mathrm{~cm} / \mathrm{s}$ では逆 に, 振動の付加により $P e$ 数は減少する場合屯ある.

多段気泡塔では, ガス流速が $3.0 \mathrm{~cm} / \mathrm{s}$ 以下では, 振動 の振幅が増大するにつれ $P e$ 数は増大し, 極大值を示し た後に減少する傾向がある. ガス流速が $8.0 \mathrm{~cm} / \mathrm{s}$ 以上で は，多段化しない場合と同様に振動の影響はほとんどな い.

$u_{G} \leqq 1.0 \mathrm{~cm} / \mathrm{s}$ では, 仕切板を設けた場合の $P e$ 数の増 加はせいぜい 1.5 倍であるのに対し，仕切板を設けぬ場 合では $2.5 \sim 3$ 倍の $P e$ 数の増加となっている. てのこと は，仕切板を設けた場合は定常流に㧊いてもすでに逆混 合が抑えられており，振動を付加しても顕著な変化は現 れないためと解釈できる。一方，仕切板がない場合では， 振動の付加が仕切板を設置したことと結果的には同様の

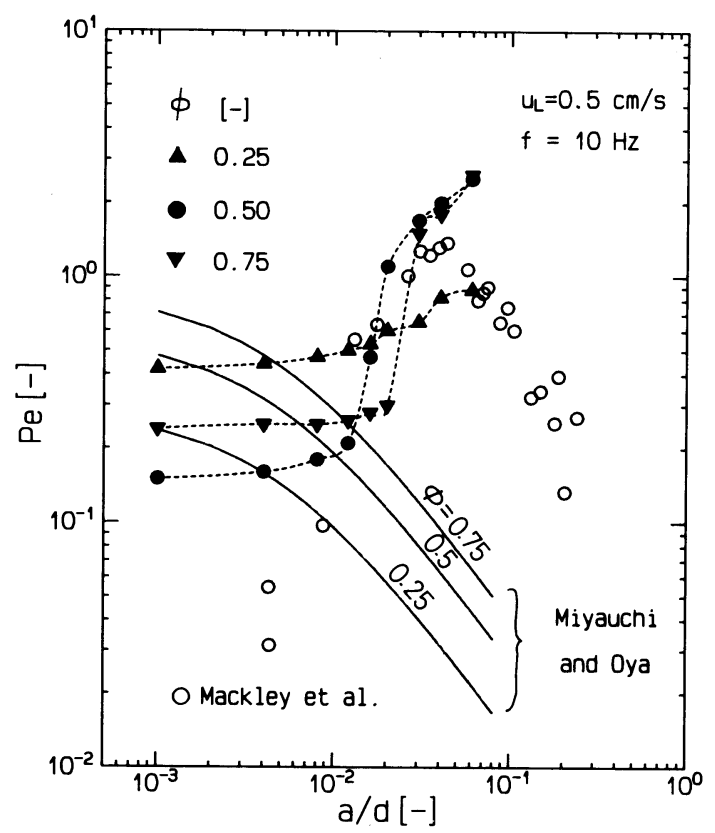

Fig. 3 Effect of fluid vibration on $P e$ number for a single phase flow in a multi-stage column

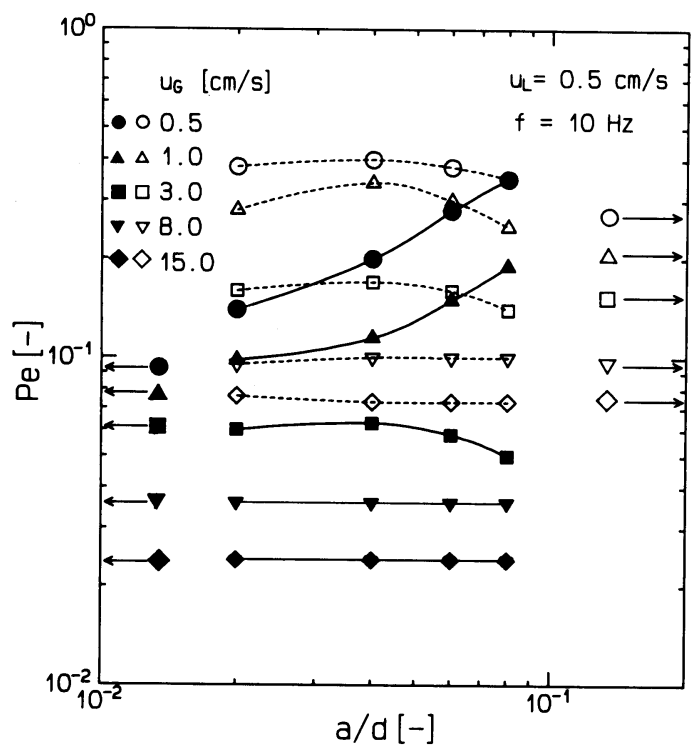

Fig. 4 Change of $P e$ number due to fluid vibration in a single-stage and a multi-stage bubble columns. Colored symbols show results for the single-stage bubble column. White symbols show results for the multi-stage bubble column.

効果を示し，逆混合の抑制として作用したものと考えら れる.

気液二相流飞振動を付加し, 流体を加速, 減速するて とによる気泡運動の変化が液混合特性へ及ぼす影響とし 
て考えられることはいくつかある.それらは気泡の振動 運動による液の摚乱, 気泡上昇速度の減少に伴う液の逆 混合の減少拈よび気泡の合体である。

気泡形が小さく球形とみなし得る場合, 振動流中での 気泡の運動方程式を積分することにより, 気泡の変動速 度として次式を得る ${ }^{1)}$.

$$
v_{B}=\frac{\rho+\rho C_{m}}{\rho_{a}+\rho C_{m}} u_{v}
$$

空気一液系では $\rho \gg \rho_{a}$ であり, また仮想質量係数とし て $C_{m}=0.5$ と仮定すると Eq. (1) より, $v_{B}=3 u_{v}$ を得る. つまり，気泡は流体の振動振幅の 3 倍の振幅で運動する。 このととは, 振動の付加により混相全体の擋乱が大きく なり，管半径方向のホールドアップが均一化し，結果と して逆混合が抑制されると考えられる。 また，振動振幅 が大きいときの塔内の気泡の運動を目視により観察した ところ, 気泡の平均上昇速度は振動を付加しない場合よ り極端に遅くなっていた，振動流中における気泡は，高 振動数では上昇せずに安定な浮遊化状態を保つことが知 られているが，液側混合の点からみると，気泡の運動速 度が遅くなることにより逆循環流が小さくなり, 液の軸 方向混合を抑える作用と考えられる．Fig. 4 亿示した低 ガス流速での $P e$ 数の増加はこのような理由によると考 えられる。

一方，振幅比が大きい場合およびガス流速が大きい場 合では, $P e$ 数は減少あるいはほとんど変化はないが, その理由は次のように考えられる，ガス流速が大きい場 合は気泡のもつ運動量が大きく, 振動を付加しても気泡 の運動の変化は小さい，また，仕切板なしで $u_{G}=3.0 \mathrm{~cm}$ /s および仕切板ありで振幅比が大きい場合では, Mackley らが得た単相流における振動の効果つまり振幅比が大き い場合に拉ける軸方向混合の助長，および気泡の合体に よる影響と考えられる.

本実験で得られた結果より，什切板を設けない気泡塔 で, 低ガス流速では流体の加速度運動により液の混合特 性を改善できることが示された。
[ 謝 辞] 本実験を行うにあたり，山本大介君，(故)宮 川修君（当時金沢大学 4 年生）には多大なるご協力を頂きまし た。 また, 北海道大学工学部の今井弘助教授には貴重な討論, ご助言を頂きました。こてに深く感謝いたします。

\section{Nomenclature}

$$
\begin{aligned}
& a \text { = amplitude of oscillation } \\
& C_{m}=\text { virtual mass coefficinet } \\
& d=\text { column diameter } \\
& d_{B}=\text { hole diameter of partition plate } \\
& E(\theta)=\text { residence time distribution function } \\
& \mathscr{D}_{L}=\text { longitudinal dispersion coefficient } \\
& \text { of liquid phase } \\
& f \quad=\text { frequency of oscillation } \\
& l=\text { column length } \\
& P e=\text { Peclet number, } u_{L} d / \mathscr{D}_{L} \\
& P e B=\text { Bodenstein number, } u_{L} l / \mathscr{D}_{L} \\
& u_{G}=\text { superficial velocity of gas } \\
& u_{L}=\text { superficial velocity of liquid } \\
& u_{v}=\text { fluctuating velocity of liquid } \\
& v_{B}=\text { fluctuating velocity of bubble } \\
& \theta=\text { dimensionless time }
\end{aligned}
$$$$
\text { [m] }
$$$$
[-]
$$$$
\text { [m] }
$$$$
\text { [m] }
$$$$
[-]
$$$$
\left[\mathrm{m}^{3} / \mathrm{s}\right]
$$$$
[\mathrm{m} / \mathrm{s}]
$$

$\left[\mathrm{kg} \cdot \mathrm{m}^{-3}\right]$

\section{Literature cited}

1) Batchelor, G.K.: "An Introduction to Fluid Dynamics", Japanese ed., p.456, Tokyo Denki Daigaku Syuppan, Tokyo, Japan (1972)

2) Dickens, A.W., M.R. Mackley and H.R. Williams: Chem. Eng. Sci., 44, 1471 (1989)

3) Harbaum, K.L. and G. Houghton: ibid., 13, 90 (1960)

4) Miyauchi, T.: Kagaku Kogaku, 24, 769 (1960)

5) Miyauchi, T. and H. Oya: AIChE J., 11, 395 (1965)

6) Nishiwaki, A. and Y. Kato: Kagaku Kogaku, 36, $1112(1972)$

7) idem: Kagaku Kogaku Ronbunshu, 1, 86 (1975) 


\title{
Change of Iongitudinal Mixing Character of Liquid in Bubble Column Due to Fluid Oscillation
}

\author{
Kenji Takahashi*, Muneyoshi Kaji, Shigeru Mori \\ and Akira Tanimoto
}

Dept. of Chem. and Chem. Eng., Kanazawa Univ., Kanazawa 920

Key Words : Bubble Column, Residence Time Distribution, Fluid Vibration, Oscillation, Virtual Mass

Effects of vibration on longitudinal mixing of liquid were studied both in a multistage and a single-stage bubble column. Peclet numbers increased with increasing amplitude of fluid vibration at low gas velocities in the single-stage column. When the gas velocities were greater than $3.0 \mathrm{~cm} / \mathrm{s}$, however, there was little change in the Peclet number in the single-stage column. In the multistage column, Peclet numbers showed maximum value when the amplitude ratio was 0.04 and when the gas velocities were smaller than $3.0 \mathrm{~cm} / \mathrm{s}$. When the gas velocities are greater than $8.0 \mathrm{~cm} / \mathrm{s}$, vibrations have no effect on the Peclet number. The effects of fluid vibration on longitudinal mixing were discussed, based on the motion of a bubble in an accelerating fluid.

* Dept. of Atomic Sci. and Nuclear Eng., Hokkaido Univ.

\section{円管内脈動流に関する複合対流物質移動の特質 ${ }^{\dagger}$ 高橋憲司 ${ }^{*} \cdot$ 川端 茂 ${ }^{* *} \cdot$ 森茂・谷本 明 金沢大学工学部 物質化学工学科 ${ }^{\dagger \dagger}$}

北浦ら ${ }^{5)}$ は気流中で振動する球からの複合対流物質移 動について次式を導いている.

$$
S h_{f v}{ }^{3}=S h_{f}{ }^{3}+S h_{v}{ }^{3}
$$

ここで, $S h_{f}$ は気流のみ, $S h_{v}$ は振動のみにおける物質 移動を表す．Jorne ${ }^{4)}$ は自然対流と強制対流が共存する 平板からの熱, 物質移動について, Eq.(1)のべき乗和の 関係と同様の結果を導いている。 また, 栗山ら ${ }^{61}$ は, 気 流中で振動しながら回転する球からの複合対流熱移動に ついて実験を行い，北浦らが得た式と同意の式により実 験結果が相関されるととを報告している.乙れらの結果

\footnotetext{
† 1992年 4 月17日受理 ; 化学工学会第 23 回秋季大会 (金沢, 1990年10月）にて一部発表

† $\mathbf{T} 920$ 金沢市小立野 2-40-20

* 北海道大学工学部 原子工学科

** ニッコー(株)
}

からは，自然対流，強制対流，振動による二次流，回転 流のいずれか複数が共存する複合対流下における熱, 物 質移動速度は，Eq.(1)のべき乗和の関係で表され，しか あ平板, 球の場合についても成立することが予想される。 しかし，北浦らおよび Jorne の研究ではいずれあ流れの 重㸚合わせが可能であるとして，個々の流れの線形和を 仮定した解析を行っている．はたして，それら流れの間 に重㸚合わせが常に適用できるのであろうか. 本研究で は, 高シュミット数に扔ける円管内定常流, 振動流拉よ び脈動流の物質移動を対象として上記問題を検討する.

\section{1. 実験装置と操作方法}

本実験では, 電気化学的方法を用いたせん断応力の測 定を行った。せん断応力測定用のテストセクションは， アクリル板を NC フライス盤で半円管状に精密に仕上げ たものを2つ作成し，それぞれの面を重祇合わせて円管 